\title{
Influence of allergic rhinitis in children and adolescents with recurrent headache
}

\author{
Authors' Contribution \\ A-Study Design \\ B-Data Collection \\ C-Statistical Analysis \\ D-Data Interpretation \\ E-Manuscript Preparatio \\ -Literature Search \\ G-Funds Collection \\ Francesco Maria Passali ${ }^{\mathrm{AB}}$, Maria Carla Spinosi ${ }^{2 \mathrm{CDE}}$, Giulia Mignacco ${ }^{2 \mathrm{DEF}}$, Cemal Cingi ${ }^{3 \mathrm{~A}}$, \\ Hugo Anibal Rodriguez ${ }^{A B}$, Desiderio Passali ${ }^{A E}$ \\ 'ENT Clinic, University of Tor Vergata, Roma, Italy \\ ${ }^{2}$ ENT Department, Policlinico S.M. alle Scotte Siena, Italy \\ ${ }^{3}$ Department of Otolaryngology Head and Neck Surgery Osmangazi University, Faculty of Medicine, Büyükdere Mahallesi, \\ Meşelik Yerleşkesi, Eskişehir, Turkey \\ ${ }^{4}$ Servicio de Endoscopia Respiratoria, Hospital de Pediatría Prof. Dr. Juan P. Garrahan, Combate de los Pozos 1881, C1245AAM \\ CABA, Buenos Aires, Argentina
}

Article history: Received: 04.01.2018 Accepted: 11.01.2018 Published: 30.04.2018

ABSTRACT: Introduction: Migraine and allergies are common occurrences. The aim of this study was to investigate the relationship between respiratory allergy and cephalalgic migraine in childhood.

Materials and Methods: We screened 800 children for headache and its characteristics. After that we investigated the presence of allergy performing prick tests, rhinoscopy, endoscopy, rhinomanometry, nasal cytology and mucociliary clearance tests.

Results: Out of 800 children screened, 96 suffered from headache. Among these, 67 resulted to suffered from both headache and allergy. We found a significant correlation between allergy and headache onset in the morning and headache onset in the evening in non-allergic subjects. The average duration of the a headache attack was independent from the presence of allergy, as well as the frequency of the cephalalgy attacks, and the localization of the pain. Prodromal symptoms connected with headache were reported to be: dizziness, aurea, sparkling scotoma, nausea and vomiting, and they were associated with absence of allergy. We also found a relationship between female gender and headache onset, but in teen-agers only. Paracetamol or FANS were used in the majority of cases, but antihistaminic therapy and/or nasal topical sprays were also reported.

Discussion: For an effective diagnostic and therapeutic approach to migraine, the pediatrician should take into account atopy and its related allergic manifestations requiring a consultation with an otolaryngologist or allergist, if necessary. Our findings also stress the potential role of medicines that are not usually utilized for migraine attacks, such as antihistamines or decongestionant nasal sprays.

KEYWORDS: $\quad$ migraine, allergic rhinitis, cephalgy, allergy, headache

\section{INTRODUCTION}

Allergy and headache are common pathologies both in adult and in children. Prevalence of migraine in pediatric population ranges from $3.3 \%$ to $21.4 \%$; it is higher in females and it increases from childhood to adolescence. [1] [2] [3]. Whereas, according to the International Study on Asthma and Allergy in Childhood, the prevalence of allergic common manifestations like asthma, allergic rhino-conjunctivitis, and atopic eczema is $8.1 \%$ among children aged between 6 and 7 years old and 10.5\% among children aged 13-14 years. [4] [5] Allergic respiratory manifestations include allergic rhinitis symptoms like nasal discharge, sneezes, pricking nose, lachrymation and respiratory difficulties with asthmatic bronchospasm and glottis or tongue edema.

Cephalalgic migraine is characterized by headache that can be associated with visual and vagus nerve symptoms (scotomas, aurea, nausea, vomiting). Often the migraine pain attack is preceded by prodromal symptoms such as dizziness or vertigo, sparkling scotomas, visual impairment. Both headaches and allergies are common in children and teenagers and they can cause significant distress and disability for young patients and their families. [6] 
Tab. I. Questionnaire to investigate headache

PRESENCE OF HEADACHE IN CHILDREN AND ITS FEATURES

Name.

Date of birth Sex ................

1. Does your child suffer or has suffered from headache?

\begin{tabular}{|l|l|}
\hline Yes & No \\
\hline
\end{tabular}

Ifyou answer "No" please do not continue filling the questionnaire.

2. Mode of onset. When the cephalalgic attack occurs?

\begin{tabular}{|l|l|l|l|}
\hline Morning & Afternoon & Evening & Night \\
\hline
\end{tabular}

3. Duration. How long does the cephalalgic attack last?

\begin{tabular}{|l|l|l|}
\hline About an hour & Between 2 and 6 hours & More than 6 hours \\
\hline
\end{tabular}

4. Frequency. How many times does the cephalalgic attack occur?

\begin{tabular}{|l|l|l|}
\hline More than twice a month & Once or twice a month & Less than once a month \\
\hline
\end{tabular}

5. Localization of pain. Where is the headache pain predominantly localized?

\begin{tabular}{|l|l|l|l|}
\hline Frontal head region & Parietal head region & Diffused & Other \\
\hline
\end{tabular}

6. Presence of warning signs. Is the cephalalgic attack preceded by warning signs?

\begin{tabular}{|l|l|}
\hline Yes & No \\
\hline
\end{tabular}

What warning signs occurred?

\begin{tabular}{|l|l|l|l|}
\hline Aurea/Scotoma & Visual impairment & Nausea/vomiting & Dizziness \\
\hline
\end{tabular}

7. Adopted therapies. What therapy/therapies is/are taken during or before the cephalalgic attack?

\begin{tabular}{|l|l|l|}
\hline Paracetamol/FANS & Nothing & Other (specificate) .......................... \\
\hline
\end{tabular}

8. Familiarity. Are there family members who suffer from headache?

\begin{tabular}{|l|l|l|l|}
\hline Mother & Father & Both & No \\
\hline
\end{tabular}

Several studies have documented the association between migraine and various comorbidities or psychosocial factors. In particular, many studies have reported associations between migraine and atopic disease such as food allergy, asthma, or allergic rhinitis. [3] [7] [8] [9] [10]

The aim of this study was to investigate the relationship between respiratory allergy and cephalalgic migraine in childhood.

\section{MATERIALS AND METHODS}

Between January 2016 and December 2016, a questionnaire
(Tab. I.) was submitted to 800 pediatric patients (411 males and 389 females) aged from 6 to 17 years (average 14 years). The questionnaire, to be filled with the help of parents, was meant to assess the presence of headache and to analyze its characteristics (mode of onset of pain, duration, monthly frequency, localization, presence of warning signs, adopted therapies andfamily history of headache). After establishing that 96 out of 800 pediatric patients had a positive anamnesis for cephalalgic symptoms, we decided to screen this sample for the presenceof allergy, performing prick tests in accordance with international guidelines (Tab. II.). [11] [12] fter that, patients underwent a standard diagnostic procedure, including anterior rhinoscopy, nasal endoscopy, rhinomanometry, nasal 
cytology for the study of nasal cells population and mucociliary clearance. [13] [14]

Anterior rhinoscopy was performed using pediatric diagnostic tools. We observed colour and trophism of septal mucosae and inferior turbinates, presence and features of nasal discharge, possible presence of nasal polyposis, since according with international studies, certain findings -such inferior turbinate hypertrophy or aqueous discharge- suggest the presence of allergic rhinitis. [15]

Before performing nasal endoscopy, two/three drops of Tramazolina Cloridrate were applied to each nostril; five minutes later, nasal examination was carried out by an expert otolaryngologist with a flexible nasal endoscope, $2.4 \mathrm{~mm}$ diameter, in accordance with international reports. [16] [17]

To perform rhinomanometry patients were asked to wear a face mask, close their mouth and breathe only with the nose in accordance with the International Committee on Standardization of Rhinomanometry. [18] [19]

A retest was performed in all patients. The results of rhinomanometry were considered related to nasal flows of $150 \mathrm{~Pa}$ and compared with pediatric reference values. height-dependent reported in literature [18] [20]. The normality threshold is set at $0.5 \mathrm{~Pa} / \mathrm{mmc}$ at 150 Pascal pressure, and values below this level were considered within the range of normality contrariwise, upper values suggest obstructive nasal flow.

Flow expressed in cc/sec and resistance expressed in Pascal were measured for the right and left nasal fossae and as overall value. Total resistance was calculated combining the resistances of the two nostrils according to the formula [21] [22]:

$\mathrm{R}_{\text {tot }}=\left(\mathrm{R}_{\text {left } \times} \mathrm{R}_{\text {right }}\right) /\left(\mathrm{R}_{\text {left }}+\mathrm{R}_{\text {right }}\right)$

In accordance with Zapletal et al. [20][23] the degree of nasal obstruction, based on rhinomanometry test values, was estimated as fraction of predicted values (p.v.) of rhinomanometric parameters:

- grade 1 corresponded to no obstruction (71-100\% of p.v.);

- grade 2 to mild obstruction (57-70\% of p.v.);

- grade 3 to moderate obstruction (43-56\% of p.v.);

- grade 4 to severe obstruction (29-42\% of p.v.) and

- grade 5 to very severe obstruction (less than $29 \%$ of p.v.)

Nasal mucociliary transport time (MCTt) was calculated by placing a tracer powder (charcoal) on the head of the inferior turbinate. The path of the powder was followed by direct pha-
Tab. II. Standard prick test panel for inhalant allergens

\begin{tabular}{|c|c|}
\hline \multicolumn{2}{|c|}{$\begin{array}{l}\text { STANDARD PRICK TEST PANEL FOR INHALANT ALLERGENS } \\
\text { HISTAMINDIHYDROCHLORIDE 0,1 \% (POSITIVE CONTROL) } \\
\text { NACI } 0.9 \% \text { (NECATIVE CONTROL) }\end{array}$} \\
\hline Hazel & Corylus avellana \\
\hline Alder & Alnusincana \\
\hline Birch & Betula alba \\
\hline Plane & Platanusvulgaris \\
\hline Cypress & Cupressussempervirens \\
\hline Grass mix & $\begin{array}{l}\text { smooth meadow grass (Poapratensis), } \\
\text { cock's foot grass (Dactilisglomerata), } \\
\text { perennial rye grass (Loliumperenne), } \\
\text { timothy grass (Phleumpratense), } \\
\text { meadow fescue (Festucapratensis), } \\
\text { meadow oat grass (Helictotrichon } \\
\text { pretense) }\end{array}$ \\
\hline Olive & Olea europaea \\
\hline Mugwort & Artemisia vulgaris \\
\hline Ragweed & Ambrosia artemisiifolia \\
\hline Alternaria & Alternaria alternata (tenuis) \\
\hline Cladosporium & Cladosporium herbarum \\
\hline Aspergillus & Aspergillus fumigatus \\
\hline Parietaria & Parietaria \\
\hline \multicolumn{2}{|l|}{ Cat } \\
\hline \multicolumn{2}{|l|}{ Dog } \\
\hline \multicolumn{2}{|c|}{ Dermatophagoides pteronyssinus } \\
\hline \multicolumn{2}{|c|}{ Dermatophagoides farinae } \\
\hline Blatella & Blatellagermanica \\
\hline
\end{tabular}

Tab. III. Onset of headache attack

\begin{tabular}{|llll|}
$\begin{array}{l}\text { ONSET OF } \\
\text { HEADACHE ATTACK }\end{array}$ & ALLERGIC (CASES) & $\begin{array}{l}\text { NON-ALLERGIC } \\
\text { (CONTROLS) }\end{array}$ & TOTAL \\
\hline At morning & 48 & 3 & $51(53,1 \%)$ \\
\hline At afternoon & 10 & 3 & $13(13,6 \%)$ \\
\hline At evening & 2 & 20 & $22(22,9 \%)$ \\
\hline During the night & 7 & 3 & $10(10,4 \%)$ \\
\hline Total & 67 & 29 & 96 \\
\hline
\end{tabular}

ryngoscopy on the posterior wall of the pharynx. The charcoal powder is an inert non soluble tracer which is trapped in the gel layer of the mucus and is transported passively by the movement of the cilia [22] [24]. Transport time was calculated as the average of the values obtained from the two nasal fossae. 


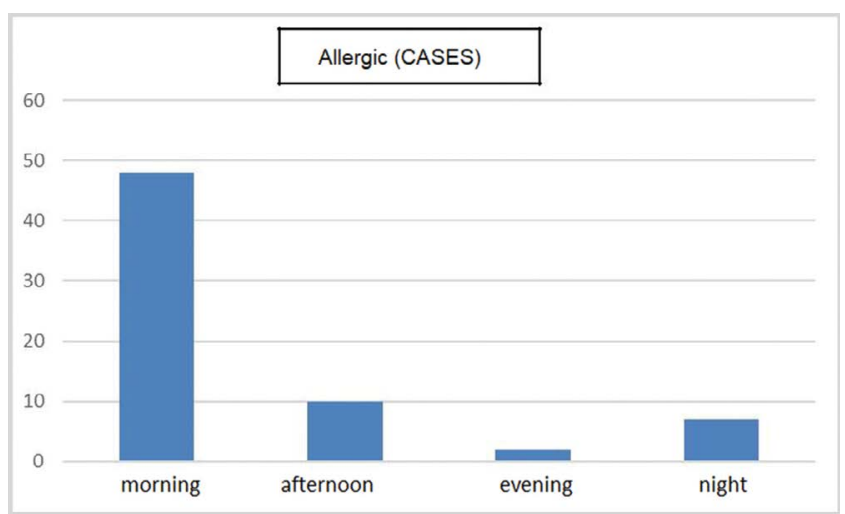

Fig. 1. Migraine onset during the day in allergic patients.

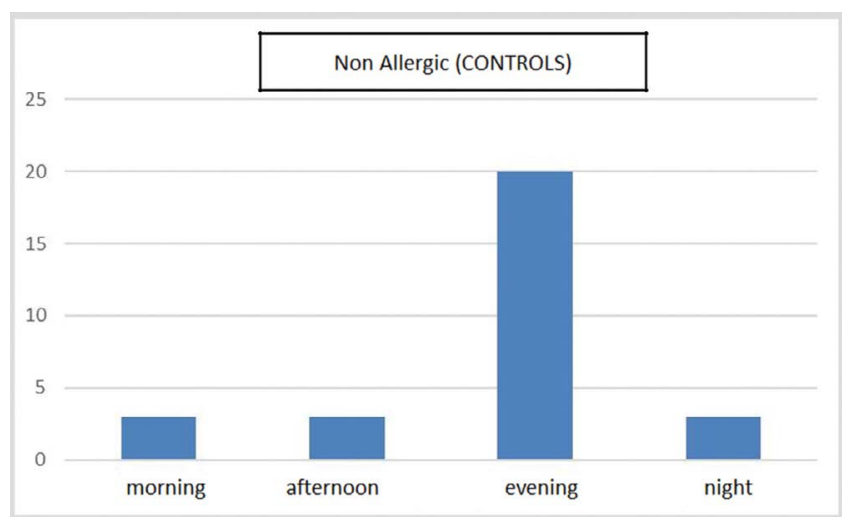

Fig. 2. Migraine onset during the day in non alllergic patients.

Moreover, parents were instructed not to use medications to their children at least 12 hours before the test.

\section{RESULTS}

\section{Headache}

Out of 800 children screened, only 96 (12\%) suffered from headache. Among those little patients, 67 of resulted to suffered from both headache and allergies (case study group), while 29 were cephalalgic only (control group).

We analyzed main clinical features of cephalalgic symptoms in our population and then we compared a few characteristics of the headache between the two groups.

We initially analyzed the dependence of allergic and non-allergic groups with the occurrence of headaches during the day in the two groups (Tab. III.).
Tab. IV. The correlation and Pvalue between allergic/non-allergic and phases of the day.

$\begin{array}{lllll} & \text { MORNING } & \text { AFTERNOON } & \text { EVENING } & \text { NIGHT } \\ \begin{array}{llll}\text { Presence of } \\ \text { allergy }\end{array} & 0,56401 & 0,06147 & -0,72082 & 0,00155 \\ \text { P value } & <, 0001 & 0,5519 & <, 0001 & 0,9881\end{array}$

Tab. V. Average duration of headache attack

\begin{tabular}{llll}
$\begin{array}{l}\text { AVERAGE } \\
\text { DURATION OF } \\
\text { ATTACK }\end{array}$ & ALLERGIC (CASES) & $\begin{array}{l}\text { NON ALLERGIC } \\
\text { (CONTROLS) }\end{array}$ & TOTAL \\
\hline $\begin{array}{l}\text { About 1 hour } \\
\text { 2-6 hours }\end{array}$ & 25 & 9 & $34(35,4 \%)$ \\
\hline $\begin{array}{l}\text { More than 6 } \\
\text { hours }\end{array}$ & 22 & 12 & $32(33,3 \%)$ \\
\hline \begin{tabular}{l} 
Total \\
\hline
\end{tabular} & 67 & 8 & $30(31,3 \%)$ \\
\hline
\end{tabular}

Tab. VI. Frequency of the cephalalgy

\begin{tabular}{|llll|}
\hline FREQUENCY OF CEPHALALCY & $\begin{array}{l}\text { ALLERGIC } \\
\text { (CASES) }\end{array}$ & $\begin{array}{l}\text { NON ALLERGIC } \\
\text { (CONTROLS) }\end{array}$ & TOTAL \\
\hline More than twice a month & 23 & 9 & $32(33,3 \%)$ \\
\hline Once or twice a month & 33 & 14 & $47(49 \%)$ \\
\hline Less than once a month & 11 & 6 & $17(17,7 \%)$ \\
\hline Total & 67 & 29 & 96 \\
\hline
\end{tabular}

Tab. VII. Localization of headache

\begin{tabular}{llll}
$\begin{array}{l}\text { LOCATION OF } \\
\text { CEPHALALCY }\end{array}$ & ALLERGIC (CASES) & $\begin{array}{l}\text { NON ALLERGIC } \\
\text { (CONTROLS) }\end{array}$ & TOTAL \\
\hline $\begin{array}{l}\text { Frontal head } \\
\text { region }\end{array}$ & 54 & 25 & $79(82,3 \%)$ \\
$\begin{array}{l}\text { Parietal head } \\
\text { region }\end{array}$ & 6 & 2 & $8(8,3 \%)$ \\
\hline Diffused & 7 & 2 & $9(9,4 \%)$ \\
\hline Total & 67 & 29 & 96 \\
\hline
\end{tabular}

Tab. VIII. Familiarity for headache

\begin{tabular}{|ll|}
\hline FAMILIARITY FOR HEADACHE & $\begin{array}{l}\text { NUMBER OF PATIENTS } \\
\text { (CASES + CONTROLS) }\end{array}$ \\
\hline Maternal & $23(24 \%)$ \\
\hline Paternal & $14(14,5 \%)$ \\
\hline Both & $2(2 \%)$ \\
\hline No familiarity & $57(59,5 \%)$ \\
\hline
\end{tabular}

As a measure of independence, we used the Cramer V, which ranges from 0 to 1 .The value of this measure was 0.743563 which indicates a clear dependence between allergy and occurrence of the headache in the different periods of the day.

Then We used Pearson's correlation index to see if there was a 
relationship between the allergic condition and the occurrence of the headache in each individual phase of the day.

We found that there was a significant and positive correlation ( 0.56401 ) between allergy and headache onset in the morning, while those who did not suffer from allergy have showed a significant correlation with the occurrence of headache in the evening hours (-0.72082). In the afternoon and at night the correlation was practically nil. Tab. IV. shows the correlation and Pvalue between allergic / non-allergic and phases of the day.

To calculate the correlations we used the variable "Presence of allergy" which is 1 in the case of allergy and 0 for non-allergy. The phases of the day are also represented by 4 dichotomous variables that are worth 1 in case of the occurrence of the headache (for each phase of the day) and 0 in the absence of headache.

The average duration of headache attack was variable in each group (Tab. V.). In fact, even if among allergic patients (case study group) the headache attack lasted for about one hour in the majority of cases, and in non-allergic group (controls) the average duration of the headache attack ranged usually between 2 and 6 hours, the correlation was -0.00580 with a P value (0.9553) close to zero. We can conclude that these parameters are independent and there isn't any relationship between presence/absence of allergy and duration of the migraine.

The correlation was calculated between the variable „Presence of allergy" and the polytomous variable „Duration” (its value was 1 in case of one-hour duration, 2 in case of 2-6 hours and3 in case of more than 6 hours).

As regards the frequency of the cephalalgy attacks (Tab. VI.), we observed that there were no significant differences between allergic and non-allergic patients; in fact, in the majority of cases, headache occurred once or twice a month in both groups (49\%).

In our sample (Tab. VII.) the cephalalgic pain was mostly localized in the frontal region (79 children, $82.3 \%$ ) and only 9 patients $(9.4 \%)$ suffered from diffused headache.

Thirty-nine children (40.6\%) had a positive familiar anamnesis history for cephalalgy (Tab. VIII.): a maternal predisposition was found in 23 patients (24\%), paternal in 14 patients $(14.5 \%)$; only 2 little patients had both parents suffering from headache. The remaining $59.5 \%$ (57 children) could not indicate a familiar predisposition to migraine attacks.

Through the Pearson correlation we analyzed the relationship
Tab. IX. Presence of prodromal symptoms.

\begin{tabular}{llll}
$\begin{array}{l}\text { PRESENCE OF } \\
\text { PRODROMAL } \\
\text { SYMPTOMS }\end{array}$ & ALLERGIC (CASES) & $\begin{array}{l}\text { NON ALLERGIC } \\
\text { (CONTROLS) }\end{array}$ & TOTAL \\
\hline Yes & 6 & 9 & $15(15,6 \%)$ \\
\hline No & 61 & 20 & $81(84,4 \%)$ \\
\hline Total & 67 & 29 & 96
\end{tabular}

Tab. X. Prodromal symptoms connected with headache.

\begin{tabular}{|ll|}
\hline PRODROMAL SYMPTOMS & NUMBER OF PATIENTS (CASES + CONTROLS) \\
\hline Aura/sparkling scotomas & 3 \\
\hline Visual impairment & 1 \\
\hline Nausea/vomiting & 13 \\
\hline Dizziness & 3 \\
\hline
\end{tabular}

Tab. XI. Gender.

\begin{tabular}{llll|} 
& $<13$ YEARS & $>13$ YEARS & TOTAL \\
\hline Female & 20 & 34 & $54(56,2 \%)$ \\
\hline Male & 26 & 16 & $42(43,8 \%)$ \\
Total & 46 & 50 & 96
\end{tabular}

Tab. XII. Drug used during or before the headache.

\begin{tabular}{|llll|}
$\begin{array}{l}\text { DRUG USED } \\
\text { DURINC OR } \\
\text { BEFORE THE } \\
\text { HEADACHE }\end{array}$ & ALLERGIC (CASES) & $\begin{array}{l}\text { NON-ALLERGIC } \\
\text { (CONTROLS) }\end{array}$ & TOTAL \\
\hline $\begin{array}{l}\text { Paracetamol/ } \\
\text { FANS }\end{array}$ & 17 & 13 & $30(31,3 \%)$ \\
\hline Other & 27 & 5 & $32(33,3 \%)$ \\
\hline Nothing & 23 & 11 & $34(35,4 \%)$ \\
\hline Total & 67 & 29 & 96 \\
\hline
\end{tabular}

Tab. XIII. Rhinomanometric values at $150 \mathrm{~Pa}(\mathrm{~Pa} / \mathrm{mmc})$

\begin{tabular}{|lll|}
\hline $\begin{array}{l}\text { RHINOMANOMETRIC VALUES } \\
\text { AT 150 PA (PA/MMC) }\end{array}$ & NUMBER OF PATIENTS & ZAPLETAL CLASSIFICATION \\
\hline$<0.5$ & $29(30,2 \%)$ & stopień 1 \\
\hline $0.5-0.7$ & $32(33,3 \%)$ & stopień 2 \\
\hline $0.7-1$ & $28(29,2 \%)$ & stopień 3 \\
\hline$>1$ & $7(7,3 \%)$ & stopień 4-5 \\
\hline
\end{tabular}

between allergic/non-allergic patients and the presence of prodromal symptoms of migraine (Tab. IX.). The two variables (presence of allergy and presence of migraine) have a correlation of - 0.27921 (P value 0.0059 ), so we can say that there is a correlation between non-allergic subjects and the presence of prodromal symptoms.

Prodromal symptoms connected with headache were repor- 
ted to be (Tab.10) dizziness, aurea, sparkling scotomas, nausea and vomiting. No prodromal symptoms were reported by the vast majority of patients $(81,84.4 \%$ of our population). Only 15 patients (15.6\%) reported the presence of neurovegetative and/or visual symptoms before or during the cephalalgic attack: the most frequent prodromal symptoms were nausea and vomiting (13 patients), while dizziness, visual impairment, aurea and scotomas occurred in 7 patients only.

Using the same above mentioned statistical analysis, we studied the relationship between the age of the patients and gender. We noticed that (Tab. XI.) there was a correlation between the variable gender ( 1 for females and 0 for males) and age of the patient ( 1 in case of younger children and 0 if they were over older than 13) is equal to -0.24694 with a P value of 0.0153 .

Finally, we investigate the therapy that the little patients implemented in case of migraine. In 34 of 96 cases (35.4\%) no specific therapy was administered. 30 patients took Paracetamol or FANs during the attack, while 32 patients (40\%) were already taking antihistaminic therapy and/or nasal topical spray Narivent [Composition: mannitol, glycerol, glicirrizinatedipotassium, PEG/PPG copolymer, sodium EDTA, sodium $\mathrm{N}$-(hyidroxy-methylil)glicinate, polysorbate 20 , potassium sorbate, sodium hydrate, purified water, natural aromas] when the pain attack occurred. Among the allergic patients the most utilized therapy during or before the headache attack was antihistaminic and/or nasal topical spray, while in non-allergic patients Paracetamol or FANS were used in the majority of cases.

\subsection{Allergic rhinitis}

According to international criteria [11] we subjected our population to prick testing: 67 out of 96 patients $(69.8 \%)$ had a positive cutireaction to one or more of the tested allergens.

The whole population (both allergic and non-allergic cephalalgic children) underwent anterior rhinoscopy. We found rhinoscopic signs of allergic rhinitis in 67 patients: pale mucous membrane, inferior turbinates hypertrophy, aqueous nasal discharge. Instead in the other $30.2 \%$ (29 patients) no signs of allergic rhinitis were observed and the anterior rhinoscopy findings were within the normality range.

Nasal endoscopy confirmed the presence of allergic rhinitis objective symptoms found in anterior rhinoscopy in all the 67 patients: pallor and dystrophy of the septal mucous membrane associated with turbinates hypertrophy and serous nasal discharge were constant findings among these patients $(69, .8 \%)$. No evidence of rhino-sinusitis was found.
Manual rhinomanometry (Tab. XIII.) performed within the whole population with the foregoing [18] [19] [20], showed that in the very same 67 patients whose prick tests have been positive, nasal pressure values exceeded the threshold set at 0.5 $\mathrm{Pa} / \mathrm{mmc}$ at 150 Pascal pressure. Twenty-nine out of 96 patients (30.2\%) had nasal pressure values lower than $0.5 \mathrm{~Pa} / \mathrm{mmc}$, so they could be classified "grade 1- no obstruction" in accordance with Zapletal classification. In 32 patients (33.3\%) there was a mild obstruction of nasal air flow (grade 2) with pressure values between 0.5 and $0.7 \mathrm{~Pa} / \mathrm{mmc}$; while in 28 children $(29,2 \%)$ a moderate obstruction was found (grade 3, pressure values between 0.7 and $1 \mathrm{~Pa} / \mathrm{mmc}$ ). Finally, only 7 cases $(7.3 \%)$ had a severe nasal obstruction (grade 4-5 of Zapletal classification) with rhinomanometric nasal pressure upper than $1 \mathrm{~Pa} / \mathrm{mmc}$.

Mucociliary transport time test with placing a tracer powder (charcoal) was performing referring to previous studies [22] [24]. Among the mentioned 67 allergic patients we found an impairment of the mucociliary function in the nose, while in non-allergic patients (29) there weren't any alterations, as insimilarly to normal children, who have shown an MCTt value of 11 minutes $( \pm 3)$ for charcoal [25].

\section{DISCUSSION}

The prevalence of cephalalgic migraine in our sample is $12 \%$, which remains in accordance with international works literature that estimates the prevalence of migraine to be between $3.3 \%$ and $21.4 \%$ in pediatric population [1] [2]. As regards the prevalence of allergic respiratory manifestations in our cephalalgic pediatric population, it was accounted for $69.8 \%$, i.e. definitely higher than in international data; in fact according to the International Study on Asthma and Allergy in Childhood, the prevalence of allergy ranges from $8.1 \%$ to $10.5 \%$ among children aged between 6 and 14 years old. [4] [5]

In order to explain this high prevalence of allergic subjects among cephalalgic children we took into consideration the etiology and pathophysiology of both migraine and allergic rhinitis.

Currently, an integrated theory of migraine that involves both vascular and neuronal components is generally accepted. It has been demonstrated that the visual aura experienced by some migraine cephalalgic patients arises from cortical spreading depression, and this neuronal event can also activate perivascular nerve afferents, leading to vasodilatation and neurogenic inflammation of the meningeal blood vessels and, thus, throbbing pain. Also hypoxia induced by chronic respiratory obstruction, especially an hypoxic condition during sleep, can lead to vasodilatation of meningeal blood vessels as a response 
to a continuous reduction in the haemoglobin oxygen saturation. Seasonal and perennial allergy can lead to reduction of nasal patency and, consequently, respiratory obstruction that can induce the cephalalgic attack. During sleep, the hypoxic condition is more prolonged and severe than the daytime; in effect, in our sample, 51 patients (53.1\%) referred that migraineous headache appears in the morning (Tab. III.).

In addition, the benefit of using medications like antihistaminic therapy and/or nasal topical spray (Narivent) during or before the migraine attack can be explained by the allergic nature of the headache.

Average duration of headache attacks was about one hour in most cases (34 patients, 35.4\%) in accordance with international studies and guidelines that analyze migraneous and non-migraneous headache features in children. [29] [30]

The frequency of migrainous cephalalgic attacks occurs once or twice a month in most cases (47 children, $49 \%$ of patients), both among allergic and non-allergic patients. This data, in line with international literature [5] [26], is representative of the social impact and discomfort caused by repeated headache attacks on the daily lives of children and adolescents and their families.

In accordance with international works [27] [28] [29], our sample reported that the migraneous pain was localized in the frontal head region in the vast majority of cases in both groups (79 children, 82,3\%); this finding could be explained, for the allergic patients, by the nasal airflow impairment. In our sample (Tab.7) the cephalalgic pain was mostly localized in the frontal region (79 children, $82.3 \%$ ) and only 9 patients $(9,4 \%)$ suffered from diffused headache.

Familiarity for headache was not a constant finding in our sample, and only 39 children (40.6\%) had a positive familiar anamnesis for cephalalgy while the remaining 57 children $(59.5 \%)$ couldn't indicate a maternal or paternal predisposition to migraine attacks. These data, that aren't in accordance with many clinical studies [25] [30] that report a positive familiar anamnesis for migraneous headache in about $70 \%$ of cases, suggest a different origin of cephalalgic pain attack, or rather headache caused by hypoxia, such allergic nasal obstruction.

Also prodromal symptoms are inconstant findings, in fact only 15 patients $(15.6 \%)$ referred the presence of neurovegetative symptoms before or during the cephalalgy; contrariwise in 81 children ( $84.4 \%$ of our sample) headache pain attacks occur without prodromal symptoms. Several international studies [32] [33] report the prevalence of prodromal symptoms in children range from $66.9 \%$ to $73.9 \%$. Therefore, this modest discordance of prevalence in our sample lies in favor of the allergic nature of migraine. Moreover, the statistical analysis performed through Paerson correlation show that there is a correlation between non-allergic subjects and the risk of prodromal symptoms. This can be explained by the different etiology of the attack of migraine, inflammatory in the case of non-allergic and hypoxic subjects in the case of allergic subjects.

In accordance with international studies [34] [35] also in our sample there is no statistically significant difference between male and female sex in children under the age of 13, while adolescents (between the ages of 13 and 19 years old) migraine headache affected females more frequently than males.

According with previous studies [35] among the 67 allergic patients we found an impairment of the mucociliary function in the nose, while in non-allergic patients there weren't any alterations as in normal children, who have a MCTt value of 11 minutes $( \pm 3)$ for charcoal.

To conclude, as suggested by our data, we found that there is a strong relation between headache and allergic rhinitis in children. Thus, for an effective diagnostic and therapeutic approach to migraine, the pediatrician should take into account atopy and its related allergic manifestations. Therefore, not only should the pediatrician investigates cephalalgic common triggers, but sneezing, asthma, atopy familiarity, nasal discharge, nasal patency as well, requesting also an otorhinolaryngologist or allergologist consult if necessary.

These findings also stress the potential role of drugs that are not usually utilized for migraine attacks, such as antihistaminic or topical nasal decongestant sprays. While paracetamol has a good analgesic effect, a targeted therapy using antihistaminic drugs could reduce onset of headache attacks and could prolong the period of well-being between consecutive attacks.

Moreover, children with migraine have an increased risk of school performance impairment, as factors associated with this impairment have already been identified

Future studies should address the directionality of the association and putative mechanisms to explain it.

\section{Acknowledgements}

Nothing to declare

\section{Funding surces}

This research did not receive any specific grant from funding agencies in the public, commercial, or not-for-profit sectors. 


\section{REFERENCES}

1. Abu-Arafeh I, Razak S, Sivaraman B, Graham C. Prevalence of headache andmigraine in children and adolescents: a systematic review of population-basedstudies. Dev Med Child Neurol. 2010 Dec;52(12):1088-97. doi:10.1111/j.1469-8749.2010.03793.x. Epub 2010 Sep 28. PubMed PMID: 20875042.

2. Antonaci F; Di Stefano AL; Galli F. The evolution of headache from childhood to adulthood: a review of the literature; J Headache Pain. $2014 ; 15(1)$ : 15.

3. Aupiais C, Wanin S, Romanello S, Spiri D, Moretti R, Boizeau P, Massano D, Zuccotti GV, Crichiutti G, Kanagarajah L, Houdouin V, Alberti C, Titomanlio L. Association Between Migraine and Atopic Diseases in Childhood: A Potential Protective Role of Anti-Allergic Drugs. Headache. 2017 Apr;57(4):612-624. doi: 10.1111/head.13032. Epub 2017 Feb 4. PubMed PMID: 28160287.

4. Asher MI, Montefort S, Björkstén B, Lai CK, Strachan DP, Weiland SK, Williams H; ISAAC Phase Three Study Group. Worldwide time trends in the prevalence ofsymptoms of asthma, allergic rhinoconjunctivitis, and eczema in childhood: ISAAC Phases One and Three repeat multicountry cross-sectional surveys. Lancet. 2006Aug 26;368(9537):733-43. Erratum in: Lancet. 2007 Sep 29;370(9593):1128. PubMedPMID: 16935684.

5. Strachan, DP, Sibbald, B, Weiland, SK et al, Worldwide variations in the prevalence of symptoms of allergic rhinoconjunctivitis in children: the International Study of Asthma and Allergies in Childhood (ISAAC). Pediatr Allergy Immunol. 1997;8:161-176.

6. Blume HK. Childhood Headache: A Brief Review.Pediatr Ann. 2017;46(4):e155-e165

7. Aamodt AH, Stovner LJ, Langhammer A, Hagen K, Zwart JA. Is headache related to asthma, hay fever, and chronic bronchitis? The Head-HUNT Study. Headache. 2007 Feb;47(2):204-12. PubMed PMID: 17300360.

8. Davey G, Sedgwick P, Maier W, Visick G, Strachan DP, Anderson HR. Association between migraine and asthma: matched case-control study. Br J Gen Pract. 2002Sep;52(482):723-7. PubMed PMID: 12236275; PubMed Central PMCID: PMC1314412.

9. Eross E, Dodick D, Eross M. The Sinus, Allergy and Migraine Study (SAMS).Headache. 2007 Feb;47(2):213-24. PubMed PMID: 17300361.

10. Ku M, Silverman B, Prifti N, Ying W, Persaud Y, Schneider A. Prevalence ofmigraine headaches in patients with allergic rhinitis. Ann Allergy AsthmaImmunol. 2006 Aug;97(2):226-30. PubMed PMID: 16937756

11. Malling HJ. Proposed guidelines for quantitative skin prick test procedure to determine the biological activity of allergenic extracts using parallel lineassay. Allergy. 1987 Jul;42(5):391-4. PubMed PMID: 3631464

12. Heinzerling L, Mari A, Bergmann KC, Bresciani M, Burbach G, Darsow U, DurhamS, Fokkens W, Gjomarkaj M, Haahtela T, Bom AT, Wöhrl S, Maibach H, Lockey R. The skin prick test - European standards. ClinTransl Allergy. 2013 Feb 1;3(1):3.doi: 10.1186/2045-7022-3-3. PubMed PMID: 23369181; PubMed Central PMCID:PMC3565910.

13. Gelardi M, Guarino R, Taliente S, Quaranta N, Carpentieri A, Passalacqua G.Allergic and nonallergic rhinitis and skin sensitization to metals: is there alink? Eur Ann Allergy ClinImmunol. 2017 May;49(3):106-109. PubMed PMID:28497672.

14. Lateef TM, Merikangas KR, He J, Kalaydjian A, Khoromi S, Knight E, Nelson KB. Headache in a national sample of American children: prevalence and comorbidity. J Child Neurol. 2009 May;24(5):536-43. doi: 10.1177/0883073808327831. PubMed PMID: 19406755; PubMed Central PMCID: PMC2794247.

15. Roberts G, Xatzipsalti M, Borrego LM, Custovic A, Halken S, Hellings PW,Papadopoulos NG, Rotiroti G, Scadding G, Timmermans F, Valovirta E. Paediatricrhinitis: position paper of the European Academy of Allergy and ClinicalImmunology. Allergy. 2013 Sep;68(9):1102-16. doi: 10.1111/all.12235. Epub 2013 Aug 19. Review. PubMed PMID: 23952296.

16. Ciprandi G, Tosca MA, Signori A, Ameli F. Comparison between symptoms andendoscopy in children with nasal obstruction. Int J PediatrOtorhinolaryngol.2010 Dec;74(12):1405-8. doi: 10.1016/j.ijporl.2010.09.019. Epub 2010 Oct 14.PubMed PMID: 20950871.

17. Ciprandi G, Klersy C, Ameli F, Cirillo I. Clinical assessment of a nasaldecongestion test by visual analog scale in allergic rhinitis. Am J Rhinol. 2008 Sep-Oct;22(5):502-5. doi: 10.2500/ajr.2008.22.3214. PubMed PMID: 18954509.

18. Zicari AM, Rugiano A, Ragusa G, Savastatano V, Bertin S, Vittori T, Duse M. The evaluation of adenoid hypertrophy andobstruction grading based on rhinomanometryafter nasal decongestant test in children.Eur Rev Med Pharmacol Sci. Nov 2013, 17(21):2962-2967

19. Clement PA. Committee report on standardization of rhinomanometry. Rhinology. 1984 Sep;22(3):151-5. PubMed PMID: 6505516.

20. Zapletal A, Chalupová J. Nasal airflow and resistance measured by activeanterior rhinomanometry in healthy children and adolescents. Pediatr Pulmonol.2002 Mar;33(3):174-80. PubMed PMID: 11836796

21. Eccles R. A guide to practical aspects of measurement of human nasal airflow by rhinomanometry. Rhinology. 2011 Mar;49(1):2-10. doi: 10.4193/Rhino10.065 Review. PubMed PMID: 21468367.

22. Passali D, Gabelli G, Passali GC, Magnato R, Platzgummer S, Salerni L, Lo Cunsolo S, Joos A, Bellussi L. Radioactive Merano SPA treatment for allergic rhinitis therapy; Int J Otolaryngol. 2016: 2801913

23. Zicari AM, Magliulo G, Rugiano A, Ragusa G, Celani C, Carbone MP, Occasi F,Duse M. The role of rhinomanometry after nasal decongestant test in theassessment of adenoid hypertrophy in children. Int J Pediatr Otorhinolaryngol.2012 Mar;76(3):352-6. doi: 10.1016/j.ijporl.2011.12.006. Epub 2011 Dec 29. PubMed PMID: 22209257.

24. Passàli D, Mezzedimi C, Passàli GC, Nuti D, Bellussi L. The role ofrhinomanometry, acoustic rhinometry, and mucociliary transport time in theassessment of nasal patency. Ear Nose Throat J. 2000 May;79(5):397-400. PubMedPMID: 10832207.

25. Martin VT, Taylor F, Gebhardt B, Tomaszewski M, Ellison JS, Martin GV, Levin L, Al-Shaikh E, Nicolas J, Bernstein JA. Allergy and immunotherapy: are they related to migraine headache? Headache. 2011 Jan;51(1):8-20. doi:10.1111/j.1526-4610.2010.01792.x. Epub 2010 Nov 4. PubMed PMID: 21054364.

26. [26]Gryglas A. Allergic rhinitis and chronic daily headaches: is there a link. CurrNeurolNeurosciRep. 2016 ; $16: 33$.

27. Passali D, Damiani V, Passali FM, Passali GC, Bellussi L. Nasalobstruction and headache. A real correlation?;Int. Journal of Pediatric Otorhinolaryngology. 
2004; Vol 68/1: 1407-1411 Jan. 2004

28. Passàli D, Bellussi L, BianchiniCiampoli M, De Seta E. Experiences in thedetermination of nasal mucociliary transport time. ActaOtolaryngol. 1984Mar-Apr;97(3-4):319-23. PubMed PMID: 6539042.

29. Raieli V, Eliseo M, Pandolfi E, La Vecchia M, La Franca G, Puma D, Ragusa D. Recurrent and chronic headaches in children below 6 years of age; J Headache Pain. 2005 Jun; 6(3): 135-142.

30. Eidlitz-Markus T, Zeharia A. Symptoms and clinical parameters of pediatric and adolescent migraine, by gender - a retrospective cohort study. J Headache Pain.2017 Aug 8;18(1):80. doi: 10.1186/s10194-017-0789-z. PubMed PMID: 28791575.

31. De Coo IF, De Jong G, Zielman R, Van den Berg JS. How general practitioners treat migraine in children. Evaluation of a headache guideline. Headache. 2014 Jun;54(6):1026-34. doi: 10.1111/head.12345. Epub 2014 Apr 25.

32. Parisi P, Vanacore N, Belcastro V, Carotenuto M, Del Giudice E, Mariani R,Papetti L, Pavone P, Savasta S, Striano P, Toldo I, Tozzi E, Verrotti A, RaucciU; "PediatricHeadacheCommission" of Società Italiana di Neurologia Pediatrica(SINP). Clinical guidelines in pediatric headache: evaluation of quality usingthe AGREE II instrument. J Headache Pain. 2014 Sep 1;15:57. doi: 10.1186/1129-2377-15-57. PubMed PMID: 25178699; PubMed Central PMCID: PMC4167157.

33. Guidetti, V., Dosi, C., Bruni, O. The relationship between sleep and headache in children: implications for treatment. CephalalgiaInt J headache. 2014;34:767-776

34. Spiri D, Rinaldi VE, Titomanlio L. Pediatricmigraine and episodic syndromes that may be associated with migraine. Ital J Pediatr. 2014 Nov 19;40:92. doi: 10.1186/s13052-014-0092-4. Review. PubMed PMID: 25928129; PubMed Central PMCID:PMC4239406.

35. Raieli V, Pitino R, Giordano G, Spitalieri C, Consolo F, Puma D, Santangelo G,Vanadia F, D'Amelio M. Migraine in a pediatricpopulation: a clinicalstudy in children younger than 7 years of age. Dev Med Child Neurol. 2015 Jun;57(6):585-8.doi: 10.1111/dmcn.12679. Epub 2015 Jan 14. PubMed PMID: 25586426.

36. Arruda MA, Bigal ME. Migraine and migraine subtypes in preadolescent children:association with school performance. Neurology. 2012 Oct 30;79(18):18818. doi:10.1212/WNL.0b013e318271f812. PubMed PMID: 23109652.

\section{Word count: 2900 Tables:13 Figures: 2 References: 36}

Access the article online: DOI: 10.5604/01.3001.0011.7252 Table of content: https://otolaryngologypl.com/issue/11198

Corresponding author: Desiderio Passali; ENT Department, Policlinico S.M. alle Scotte; Siena, viale bracci n.16, 53100, Italy; Tel.: +39 0577/585470; E-mail: d.passali@virgilio.it

Copyright $\odot 2018$ Polish Society of Otorhinolaryngologists Head and Neck Surgeons. Published by Index Copernicus Sp. z o.o. All rights reserved.

Competing interests: The authors declare that they have no competing interests.

Cite this article as: Passali F., A., Spinosi M., C., Mignacco C., Cingi C., Rodriguez H., A., Passali D.; Influence of allergic rhinitis in children and adolescents with recurrent headache; Otolaryngol Pol 2018; $72(2): 48-57$ 
